\title{
Hybrid identities? Trajectories of the Lives of Women with Acquired Disabilities
}

\author{
Dorota Żuchowska-Skiba \\ AGH, Akademia Górniczo-Hutnicza w Krakowie
}

DOI: http://dx.doi.org/10.18778/1733-8069.16.3.05

\section{Keywords:}

identity, women with disability, acquired disability, physical disability, turning point

\begin{abstract}
In the study of disability, an extremely important role is played by issues related to identity changes occurring under the influence of experiences which alter the current course of life and force the adoption of new roles and the adaptation of previously fulfilled roles. This is the nature of a disability acquired in adulthood. It is a turning point that transforms the identities of women who must redefine themselves and their places in a reality that is new to them.

The main goal of the article will be to show the changes that affect the identities of women who, as a result of an accident, acquired disability in adulthood. The study is based on autobiographical narrative interviews. This method allowed me to reconstruct the trajectory of the lives of the respondents, showing the process-like nature of the identities they shape, which have undergone changes under the influence of the need to adapt to the conditions resulting from the acquired disability. Six women - diversified in terms of age, education, professional position, and family situation, all of which influenced their roles and social positions - were surveyed.
\end{abstract}

Dorota Żuchowska-Skiba, PhD - AGH University of Science and Technology, Faculty of Humanities. Research interests include the analysis of mass media, especially new media, together with the prospect of collective action taken in the social and virtual reality. Particular attention is paid to new forms of social activity and the public, civic, and political society in the era of the network for people with disabilities and other excluded or marginalized groups.

\section{Contact details:}

AGH

Akademia Górniczo-Hutnicza

Wydział Humanistyczny

ul. Gramatyka 8a

30-071 Kraków

email address: zuchowska@agh.edu.pl; zuchowskadorota@gmail.com 


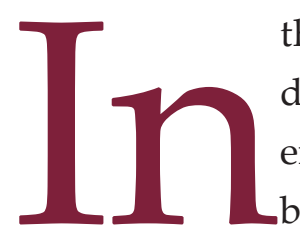

the relational (Nordic) approach, disability is presented as a phenomenon constructed in the interaction between physical, mental, and sensory deficits of people with disabilities and the barriers inherent in the socio-economic organization and the environment in which they function (Campbell 2009:95). It is a complex relationship between the limitations inherent in individuals and the expectations of society (Wendelborg and Tøssebro 2010:701714). As a result, people with disabilities are excluded from society due to the mismatch between social expectations and their biological abilities (Tøssebro 2004; Goodley 2011:18). In such an approach, the position of people with disabilities depends both on the type and degree of disability as well as on the limitations and requirements imposed on them by society.

The complexity of contemporary societies and their diversity requires looking at the process of marginalization of people with disabilities from the intersectional perspective (Goodley 2011). This makes it possible to show the importance of multiple positionalities for the search for differences between social groups as well as for enabling the identification of mutually influencing factors that affect life and contribute to the existence of inequalities in contemporary societies (Goethals, De Schauwer, and Van Hove 2015). In this approach, individuals are devoted to multi-dimensional discrimination based on disability, gender, religion, income, age, cultural origin, family status, and many other factors that are interrelated and determine their position in society (Hancock 2007).

Previous studies show that women with a disability are experiencing double discrimination, i.e. based on both gender and disability (Brooks and Deegan
1981; Ferri and Gregg 1998:429; Moser 2006; Ciaputa, Król, and Warat 2014; Ciaputa et al. 2014; Deegan 2018). The situation of women with disabilities is worse than men's, both economically and socially (Nosek and Hughes 2003). Both genders experience discrimination based on disability, but men face fewer barriers to achieving life goals than women do, and have a better chance of achieving typically male roles (Asch and Fine 1988; Nosek and Hughes 2003:229-230). It all consists in the refusal to let women exercise certain gender roles - especially maternal and educational - due to the disability (Asch and Fine 1988:13; Finger 1991; Thomas 1997; Wołowicz-Ruszkowska 2013; Ciaputa et al. 2014). This is the result of cultural expectations for women with disabilities, which often ignore or repress their sexuality, professional work, and motherhood, which excludes them from the traditional roles of wives, employees, and mothers (Finger 1992; Morris 1993; Barnes and Mercer 2008:74; McDonald, Keys, and Balcazar 2007). Bodily aspects showing women as asexual and physically unattractive were also important in the marginalization of women with disabilities (Begum 1992:81; Asch and Fine 1997; Milligan and Neufeldt 2001; Król 2018:88). As a consequence, negative social perceptions about women with disabilities reduced their self-esteem and contributed to their building negative definitions of their Selves (Walsh and Walsh 1989; Brooks and Matson 1982; Craig, Hancock, and Chang 1994; Nosek 1996; Barnwell and Kavanagh 1997).

This shows that the gender of people with disabilities is one of the important factors shaping the self-image of people with disabilities and emerging under the influence of the social perception of disability (see: Kumaniecka-Wiśniewska 2006:61; Thomas 1999:47). In this context, it becomes important to reveal the significance of gender for identities 
shaped by people with disabilities (see: Forber-Pratt et al. 2017).

The purpose of the article is to demonstrate the identities built by women with motor disabilities, who lost their fitness in adulthood; it is to reveal what changes they are undergoing under the influence of having acquired a disability and confronting stereotypical ideas about disability at some stage of life.

\section{Study on disability identity development}

Research on the identity of people with disabilities conducted by Kathy Charmaz (1995) has showed that disability often appears in human life unexpectedly -i.e. as a consequence of illness or accident - and results in the need for adaptation, which forces a change in life and the need to build a definition of oneself adjusted to the limitations of one's body. In this understanding, the identity of a person is a construct of mutually interacting individual and contextual variables resulting from situations that the individual had encountered (Simon 2004). Therefore, identity might be subject to certain adaptations and changes in response to situational pressures experienced by individuals (Deaux 1993; 2001; Oyserman 2004). This process takes place under the influence of assessments coming from the social environment; as a result, the individual changes the picture of themselves, which leads to a change in their identities (Dolch 2003:373). This points to the processual nature of identity, which is being constructed and reconstructed throughout the entire life of the individual (Jenkins 2005:3-4).

Anselm Strauss's concept $(1959,2013)$ allows for looking at identity as a process in which it is subject to constant negotiations and changes resulting from interactions between the individual and their social environment (Strauss 1995; Konecki 2015:17).According to this concept, changes in identity are the consequence of critical incidents, referred to as "turning points," which means that a person - in the face of new facts or events - has to revise their views and opinions, and look at many matters in a new light in order to assess them (Strauss 1959:92). Biographical situations generate many critical incidents which influence significant changes in identity that is being realized during the analysis of the history of one's life (Strauss 1959:93). As a result, people are constantly composing and revising their autobiographies, and the changes taking place in the images created by social actors and their interpretation constitute "critical points" in the development of their identities (Carr 1986:76). As a consequence of this process, self-image might change under the influence of events significantly affecting the image of oneself (Hormuth 1990; Ethier and Deaux 1994). In critical situations, the existing identities can be challenged and new identities replace them (Deaux 2001).

This is the nature of the acquisition of a disability, which imposes critical reflection on one's life and causes changes in identity because of the need to include the disability in the image of oneself (Frank 1993; Charmaz 1995). The image of Self changes and so does the relationship between the individual and their environment, which is communicated in feedback relations (Piątek 2009). The existing identity must be supplemented with new aspects resulting from the need to define oneself and one's place and roles in society in relation to the disability. This causes identity hybridization. The concept of hybrid identities appears in the literature on the subject in relation to a situation where the individual "lives between different cultures" and experiences what has been referred to as "cultural hybridity" (Burke 2009:4), which is due to the decision to immigrate 
and the need to live in another country (Stojkow and Żuchowska-Skiba 2018), or getting married or entering into a relationship with a person of a different nationality (Gonçalves 2013). This term can also be found in cultural studies and media. It appears as a consequence of mixing genres and reconciles contradictions by combining elements and eliminating inconsistencies (Szczęsna 2004:9). Because a similar process takes places in the case of people with acquired disabilities in relation to the identities they are building, it seems reasonable to use this concept in order to show the process of identity changes taking place as a result of the loss of efficiency. Previous analyses on the identities of women with physical disabilities concerned the relationship between disability and sexuality, body image, and life satisfaction. They revealed that although women with physical disabilities had the same sexual needs and desires as women without disabilities, their self-esteem, perception of their own bodies, and satisfaction with sex life - and overall life satisfaction - were all significantly lower than among able-bodied women (Moin, Duvdevany, and Mazor 2009). Similar results were obtained by Alison Beckwith and Matthew Kwai-SangYau (2013) in the study of women with spinal trauma. They noticed that the problems faced by the respondents concerned the social perception of people with motor disabilities. The negative image of physical disability functioning in society affected the perception of their own bodies by women with disabilities, which translated into their lower self-esteem (Nosek and Hughes 2003; Taleporos and McCabe 2002). It also resulted in a higher sense of social isolation, which deepened the sense of exclusion (Nosek et al. 2003). Research on the identities of women with physical disabilities shows that contextual, physical, social, and emotional dimensions of disability affect self-built images (Nosek and Hughes 2003; Hughes et al. 2003).

\section{Trajectories of the fate of women with acquired disability - Research method}

The primary goal of the research was to show the changes that affect the identities of women who acquired a disability as a result of an accident. In this case, the acquisition of the disability was a turning point that caused significant changes disrupting the orderly development path of the respondents. The purpose of the analysis was to present the trajectory of constructing identities by women with motor disabilities acquired in adulthood as a result of trauma. This made it possible to understand the processes occurring under the influence of external events throughout the life of the individual, which were beyond their control and were a kind of suffering, i.e. the acquisition of permanent disability. It also allowed for the reconstruction of how disability affected their self-definitions and perception of themselves in relation to social expectations in terms of fulfilling roles (see: Riemann and Schütze 1992; Kubicki 2017).

To examine the identities of women with disabilities acquired in adulthood, I used biographical narrative interviews that allowed the respondents to recreate ways of understanding themselves and their own lives (see: Strauss 1959:96). The use of this research method allowed for the recreation of the processual logic of events and the resulting experiences that influenced the self-image of the respondents and, consequently, shaped their identities (Hermanns 1987:50). The interview was divided into three basic areas. The first one included changes in self-image in relation to one's own disabled body and the loss of independence resulting from the disability. The second one was related to the change in the definition of self in response to the social image of disability and the perception of women with motor disabilities. The 
third one involved changing the roles and ways of fulfilling them by women with disabilities in the context of barriers and restrictions as well as prejudices and stereotypes existing in society. This made it possible to reveal the changes in the identities of the respondents as a result of an accident and the disability. These three research fields were intertwined within the statements from the respondents. This shows that the experience of disability had a strong influence on both the self-definitions of the respondents and the roles they fulfilled as well as stereotypical images with which they had to deal with in everyday life. Therefore, they were treated together at the level of analysis.

The sample selection was deliberate. The study was preceded by the observation of the Internet in the period September-October 2009 with the aim of selecting blogs and Facebook profiles devoted to the subject of coping with disability resulting from an accident. As a consequence, contact was established with ten women who shared their experiences in this regard with other users. Six women participated in the research and were interviewed via Skype. The interviews were recorded and transcribed. All the quotations used in this article were translated from the Polish language.

Table 1. Characteristics of the respondents

\begin{tabular}{|l|lll|}
\hline & age & education & place of residence \\
\hline Interview 1 & 28 & higher & medium-sized city \\
\hline Interview 2 & 32 & higher & large city \\
\hline Interview 3 & 37 & secondary & village \\
\hline Interview 4 & 42 & secondary & small city \\
\hline Interview 5 & 49 & secondary & medium-sized city \\
\hline Interview 6 & 52 & secondary & large city \\
\hline
\end{tabular}

Source: Self elaboration.
The study involved interviewing six women with motor disabilities, which they acquired as a result of an accident at least two years before the study. Five of the respondents used a wheelchair and one used a specialized walker or crutches. Two of the respondents lived in a large city, two in medium-sized cities, one in a small town, and one in the countryside. Four of the respondents had acquired secondary education, and two had obtained higher education. They had graduated before acquiring the disability. Before the development of the disability, all of them had been professionally active and remained in formal or informal relationships. Four of the respondents had children, who had been born at an earlier stage in life. In addition, all of the respondents ran blogs, video blogs, Facebook profiles, or portals where they would describe their lives as well as share experiences and give advice on cooking, raising children, fashion, beauty, and sex; they also offer psychological, legal, and counseling support to other women with disabilities as well as their partners and families.

\section{Study results}

The conducted research showed that in the biographical interviews, the surveyed women distinguished between two periods of coping with their disability and building a new self-image. The first one, which began immediately after acquiring the disability, was defined as the time of "experiencing" disability and learning it. During this period, the respondents learned about their limitations and had to face the acceptance of the new situation and their own disabled bodies. At that time, issues of social roles, relationships with the environment, and the sense of femininity remained suspended. The respondents gave up activities undertaken before the accident. They also avoided undertaking new activities for fear of failure. 


\section{Stage one: Experiencing disability}

The interviews indicated that all of the respondents treated the moment of disability acquisition as a turning point in their biographies. The lives as they had known them were now disrupted by the accident. As a result, the previous orderly development path which they had built was broken, which changed their position and forced a modification of life plans. One of the respondents said:

I could not handle the situation; I was angry that it happened to me. I had a good job, a boyfriend, a planned wedding, and I lost it all in an instant. The accident and disability meant that everything changed, the endless search for therapy - increasingly bizarre - to help me, blaming myself and others for what happened. Formerly an independent, resourceful, and happy woman, I became helpless, in need of help. (interview1)

The sense of dependency that suddenly appeared was a factor that negatively affected the self-esteem of the respondents. Another respondent said:

The worst thing was the feeling of powerlessness and total dependence on others. Until then, it had been I who organized everything: holidays, trips, school; and now I felt dependent on the help of others. I had the impression that I was no longer needed and I was only a burden. (interview 5)

A resignation from undertaking previous activities and activities related to the implementation of roles fulfilled in this period was a necessary stage for the respondents. They felt that the past was over, but could not yet decide how they would function in the new situation. This time was a transitional period (see: Strauss 2013:95). They invested a lot in building their professional, family, and social position, and it was difficult for them to accept the loss of what they had achieved so far. In addition, they had stereotypical perceptions about people with disabilities and disability acquired before the accident, which were of a negative character. This further strengthened their sense of fear of what awaited them in the future. According to the respondents, relationships with the environment in the first months after acquiring the disability were based on compassion. As a result, they felt they had to be grateful for the kindness and help of others, but they felt rather lost and scared or furious about their disability. This meant that they often withdrew from relationships to avoid situations in which they felt emotional discomfort.

In the interviews, the women also said that the acquisition of the disability significantly influenced their perception of their own disabled bodies, which resulted in changes in the image of themselves and forced modifications in defining themselves. In the first months after the accident, they saw themselves only through the prism of disability, which negatively affected their self-esteem and sense of femininity. One of the women said:

What had been indistinguishable before the accident, so common, now became a problem and suddenly became very valuable. Everything had to be re-evaluated, but it was hard for me to reconcile that what had been in my life just present so far suddenly no longer mattered as a result of the accident. Roots and a terrible haircut had been hard to bear, but then everything became about my disability; it was the most important thing. (interview 6)

Another respondent, talking about the first months after the accident, emphasized the changes that had 
occurred in relation to her body and its perception by the social environment, i.e. both relatives and medical staff(doctors, physiotherapists, therapists):

Check-ups and examinations, which I had to undergo quite often right after leaving the hospital, were the most difficult thing. I was ashamed, on the one hand, of unshaven legs, neglected hands and feet, and, on the other hand, I felt guilty for feeling this shame. It seemed so shallow. Everyone around me was focused on my health and fitness, and I was concerned about my appearance. It was very difficult; I realized that I was no longer a woman but a medical case. (interview 3)

This feeling of guilt that one wants to take care of their own body and improve its aesthetics was present at this stage in all surveyed women, although not all of them spoke about it in a direct way. Statements indicated that in this new situation in which they found themselves, the sense of physical attractiveness must have fallen aside in relation to other "more important issues." What mattered at that time was regaining at least partial fitness, learning to live with the disability, and accepting dependence on others. The respondents felt neglected and felt discomfort, but they faced up to it as they felt that how they looked like was not the most important thing at that time. According to the women, during this period disability dominated all aspects of their lives, including femininity. One of the respondents said:

I could not afford to think about my appearance, even about new clothes, although the old ones did not fit in the new situation at all, because I could not put them on without the help of others. As a result, for many months my 'uniform' consisted of a tracksuit and T-shirt. It is hard to feel feminine in this situation. (interview 2)
The respondents claimed that the feeling of physical unattractiveness had a negative impact on their relationships with their partners. As they were ashamed of their own bodies, dissatisfaction with their own appearance brought fear of intimate intercourse. In addition, due to disability, they were afraid of being active in this area. They also claimed that no one had informed them about the restrictions and they had not received any support from medical staff or numerous specialists with regard to changes that would occur in their experience of sexuality due to trauma.

Doctors said it heals well. Nurses joked that the scars would be almost invisible. Physiotherapists said that I was making progress ... But no one talked to me about what would change in my body, whether I would be able to be a wife for my husband also in this intimate dimension. I was ashamed to ask, everyone was so focused on my health and fitness, and I wanted to ask if I would have any more sex life. At that time, such a question seemed absurd to me. (interview 4)

After some time, lasting from four to seven months, the women - alongside learning about their capabilities and limitations, and accepting changes in appearance - began the next stage of building their self-image and redefining their identities.

\section{Stage 2: Compromises in constructed identities}

At the second stage, the surveyed women corrected their plans and rebuilt their self-images. In their opinion, this process continues to this day, despite the fact that at least two years have passed since they acquired their disability. According to the respondents, since disability appeared in their lives, they have had to constantly redefine their goals in 
relation to the possibilities they had as well as they are facing stereotypical ideas about people with disabilities and society's expectations commonly present in the culture. This had an impact on the self-esteem of the respondents and resulted in constant changes in their self-definitions, which were modified both under the influence of social expectations and their own limitations in a dynamic and situation-dependent manner. This is illustrated by the statement:

The hardest thing for me to get used to was pity from others. The words 'so young, so pretty and in a wheelchair' showed that others only saw my disability and that it was the most important for them. I had a feeling that whatever I did, I would still be the one in the wheelchair. With time I got used to it and I don't care anymore. (interview 4)

At this stage, the respondents tried to return to their previously fulfilled roles and the activities that they had undertaken before the accident. All of the respondents said that with time they had ceased to focus solely on their disability, and had begun to focus on tasks and goals covering other areas of everyday life, e.g. cooking, helping children at school, or looking for job opportunities. Social expectations prevented them from returning to activities performed before the accident. According to the women, the reconstruction of self-images at that time was related to the perception of disability in society and stereotypical images that excluded them from the roles they had previously fulfilled. At this stage, the respondents had to face the barriers inherent in society and culture, and re-build their identity in a collision with what was achievable for them not only in the physical but also in the social dimension. All of the women said that the environment denied them many activities and needs, and hindered ac- cess to social roles. Above all, the respondents raised the issues with caring for their own physical attractiveness. At this stage, all of the respondents had to fight for the recognition of their right to improve the aesthetics of their appearances. One of the women said:

I knew I would spend my whole life in a wheelchair. I felt terrible sitting in it in an old faded tracksuit. I was convinced that no one saw me as a woman, but a person - or a sexless creature - in a wheelchair. I could not accept it; it was hard for me to convince my loved ones, especially my mother, that we had to go shopping for a few things that would look nice and be easy to put on. I had to fight for what used to be normal. (interview 1)

According to the women, the type of problems they had to deal with changed at this stage; they were less and less often associated with disability and more and more often they were similar to those they had struggled with before acquiring the disability. All of the respondents said that once they had reconciled with their disability, they had gotten to know its consequences and had accepted their otherness, they could focus on expanding their capabilities and regaining independence wherever possible. One of the women said:

The overprotection of my parents made me feel isolated from life. I could not do anything myself. My parents tried to organize everything for me and do everything for me. They were baffled when I decided to return to my home and job. Although I was not a child anymore, they still treated me like one. They treated my idea for the future and the will to live independently with indulgent kindness, and discouraged me, continuously emphasizing that I could not cope alone. (interview 2) 
When asked about how they perceived themselves as women, the respondents referred to the idealized image of femininity being about fulfilling caring and sexual roles, caring for the home and themselves. In their statements, the interviewees focused on their limitations in fulfilling roles and on the experienced exclusion from fulfilling them. One of the women said:

The woman must cook, wash and do everything around the house - and me? According to my relatives, I am something like a mother, wife and woman, but it is not the same. According to able-bodied people, acquiring a disability means the loss of a part of femininity. According to others, if I am in a wheelchair, I am not capable of fulfilling the role of mother or wife - but this is just a harmful stereotype. (interview 3)

The important issue of sexuality would also appear in the interviews. The respondents emphasized that they were seeking advice on sex life after the injury on their own. They did not want to give it up, but getting information and sexual rehabilitation was very difficult. The women said how they were most exposed to exclusion and discrimination in this area. They emphasized that even regular visits to the gynecologist now had a definitely different course than before the accident. One of the women said:

Women in wheelchairs have typical female problems, e.g. inflammation or yeast infection, they need contraception and normal gynecological examinations. Along with disability, it suddenly turned out that what was necessary before the accident- e.g. cervical smears every two years - was now completely unnecessary. As if a woman with a disability suddenly lost her organs that biologically make her a woman. (interview 5)
Another respondent said:

The doctor did not even see the need for a gynecological examination, he limited himself to an interview. I was married, yet in the eyes of the doctor I was not a woman who could normally live with her husband. (interview 6)

According to the interviewees, this was not medically justifiable and resulted only from the stereotypical perception of women with motor disabilities as asexual.

\section{Concluding Remarks}

Research shows that the identities of women with acquired disabilities are hybrid. The constructed identities were still not fully defined and can be described as "incomplete" and "unclosed" (see Szczęsna 2004). They enabled the respondents to function in the here and now while remembering what had once been and waiting for what will be in the future. The women emphasized that they were still in the period in which they negotiated the final shape of their identity as women with disabilities. During the interviews, the respondents defined themselves as persons with disabilities as well as women. These self-definitions were inextricably linked and created a coherent self-image in the biographical narratives of the women. However, it can be seen that in the context of the exclusion processes that the respondents experienced, they more often referred to themselves as persons with disabilities, while in relation to everyday life and undertaken activities - as women. This shows that in many areas disability played a more important role in their perception of themselves, while in others femininity came to the fore. In their statements, the interviewees emphasized that one could "be 
a woman despite disability, have a loved one and be loved" or said that "even a woman in a wheelchair can look good with the right clothes and makeup," or "despite the wheelchair I work and I am a woman, wife, and mother of two wonderful kids." This shows that, in their opinion, femininity was an element of identity that existed next to disability and was equally important to their self-image. The results of the analysis reveal that in the initial period after the injury this balance was disturbed and the perception of self as a person with a disability dominated all goals, activities, and actions. This also referred to caring for physical attractiveness and sex life, and fulfilling the roles of wife and mother, which at that time were pushed into the background. Only with time did femininity appear in the self-definitions of the respondents as an element of their identities that was equally important to disability, which allowed the wom- en to build new positive identities. However, the respondents emphasized that this required them to go beyond the self-imposed restrictions and to resist pressure from their immediate surroundings. For this reason, the interviewees decided to act for other women with disabilities and support them, offering advice and experience in dealing with everyday problems, and strengthening their feeling that disability does not necessarily mean giving up femininity and gender roles, even if it is contrary to what society expects from them. According to the respondents, only women with disabilities themselves can force changes in how society treats them. It is not easy, because they have to face deeply rooted stereotypes-according to which they also had been brought up and shaped -as well as they lack role models who are showing women with disabilities that various roles can still be performed, which also affects their life choices.

\section{References}

Asch, Adrienne and Michelle Fine Michelle. 1988. "Introduction: Beyond pedestals." Pp 1-37. in Women with disabilities: Essays in psychology, culture, and politics, edited by A. Asch and M. Fine. Philadelphia, PA: Temple University Press.

Asch, Adrienne and Michelle Fine. 1997. "Sexuality and Women with Disabilities: The Example of Women and Literature." Pp. 241-255 in Disability Studies Reader, edited by L. Davis. New York, London: Routledge.

Barnes, Coli and Geof Mecer. 2008. Niepetnosprawność. Warsaw: Sic!

Barnwell, Alice M. and David J. Kavanagh. 1997. "Prediction of psychological adjustment to multiple sclerosis." Social Science and Medicine 45:411-418.

Beckwith, Alison, and Matthew Kwai-Sang Yau. 2013. “Sexual recovery: Experiences of women with Spinal injury recon- structing a positive sexual identity." Sexuality and Disability 31:313-324.

Begum, Nasa. 1992. "Disabled Women and the Feminist Agenda." Feminist Review 1(40):70-84.

Brooks, Nancy and Mary Jo Deegan. 1981. “Women and Disability: The Double Handicap." The Journal of Sociology and Social Welfare 2(8):229-231.

Brooks, Nancy A., and Ronald R. Matson. 1982. "Social-psychological adjustment to multiple sclerosis: A longitudinal study." Social Science and Medicine 16(24): 2129-2135.

Burke, Peter. 2009. Cultural hybridity. Cambridge: Polity Press.

Campbell, Fiona K. 2009. Contours of Ableism: Territories, Objects, Disability and Desire. London: Palgrave Macmillan. 
Carr, David. 1986. Time, narrative and history. Bloomington, IN: Indiana University Press.

Charmaz, Kathy. 1995. “The body, identity, and self: Adapting to impairment." The Sociological Quarterly 36(4):657-680.

Ciaputa, Ewelin, Agnieszka Król, and Marta Warat. 2014. "Genderowy wymiar niepełnosprawności. Sytuacja kobiet z niepełnosprawnościami wzroku, ruchu i słuchu." Pp. 153174 in Polscy niepetnosprawni: od kompleksowej diagnozy do nowego modelu polityki społecznej, edited by B. Gąciarz and S. Rudnicki. Cracow: Wydawnictwo AGH.

Ciaputa, Ewelina et al. 2014. "Macierzyństwo kobiet z niepełnosprawnościami ruchu, wzroku i słuchu." Studia Socjologiczne 2(213):203-224.

Craig, Ashley R., Karen Hancock, and Esther Chang. 1994. "The influence of spinal cord injury on coping styles and self-perceptions two years after the injury." Australian and New Zealand Journal of Psychiatry 2(28):307-312.

Deaux, Kay (1993) "Reconstructing social identity." Personality and Social Psychology Bulletin 19(1):4-12.

Deaux, Kay. 2001. "Social identity." Pp. 1059-1068 in Encyclopedia of women and gender, edited by J. Worrell. San Diego, CA: Academic Press.

Deegan, Mary Jo. 2018. Women and disability: The double handicap. New York: Routledge.

Dolch, Norman A. 2003. "Role." Pp. 391-410 in Handbook of Symbolic Interactionism, edited by L. T. Reynolds and N. J. Herman-Kinney. Walnut Creek: Alta Mira Press.

Ethier, Kathleen A. and Kay Deaux. 1994. “Negotiating social identity when contexts change: Maintaining identification and responding to threat." Journal of Personality and Social Psychology 2(67):243-251.

Ferri, Beth A. and Noel Gregg. 1998. "Women with disabilities: Missing voices." Women's Studies International Forum 4(21):429-439.

Finger, Ann. 1991. Past Due: A Story of Disability, Pregnancy and Birth. Seattle: Seal Press.

Finger, Ann. 1992. "Forbidden Fruit." New Internationalist 233:8-10.
Forber-Pratt Anjali J. et al. 2017. "Disability identity development: A systematic review of the literature." Rehabilitation Psychology 62:198-207.

Frank, Ann W. 1993. "The rhetoric of self-change: illness experience as narrative." The Sociological Quarterly 1(34):39-52.

Goethals, Tina, Elisabeth De Schauwer, and Geert Van Hove. 2015. "Weaving Intersectionality into Disability Studies Research: Inclusion, Reflexivity and Anti-essentialism." Journal for Diversity and Gender Studies 2(1-2):75-94.

Gonçalves, Kellie. 2013. “'Cooking lunch, that's Swiss': Constructing hybrid identities based on socio-cultural practices." Multilingua 4(432):527-547.

Goodley, Dan. 2011. Disability Studies. An Interdisciplinary Introduction. London: Sage.

Hancock. Marie A. 2007. “When Multiplication Doesn't Equal Quick Addition: Examining Intersectionality as a Research Paradigm." Perspectives on Politics 1(5):63-79.

Hermanns, Harry. 1987. "Narrative interview - a new tool for sociological field research." Acta Universitatis Lodziensis: Folia Sociologica 13:43-56.

Hormuth, Stefan E. 1990. The ecology of the self: Relocation and self-concept change. Cambridge: Cambridge University Press.

Hughes Rosemary B. et al. 2003. "Health promotion for women with physical disabilities: A pilot study." Rehabilitation Psychology 3(48):182-188.

Jenkins, Richard. 2005. Social Identity. London, New York: Routledge.

Konecki, Krzysztof T. 2015. "Anselm L. Strauss-Pragmatic Roots, Pragmatic Implications." Przeglad Socjologii Jakościowej 1(11):12-39.

Król, Agnieszka. 2018. “Niepełnosprawność i sprawiedliwość reprodukcyjna. Zarys wybranych zagadnień dotyczących kobiet z niepełnosprawnościami." Annales Universitatis Paedagogicae Cracoviensis. Studia de Cultura 1(10):84-99.

Kubicki, Paweł. 2017. Polityka publiczna wobec osób z niepetnosprawnościami. Warsaw: Oficyna Wydawnicza SGH Szkoła Główna Handlowa w Warszawie. 
Kumaniecka-Wiśniewska, Agnieszka. 2006. Kim jestem? Tożsamość kobiet upośledzonych umysłowo. Warsaw: Wydawnictwo Akademickie.

McDonald, Katherine E., Christofer Keys, and Fabricio E. Balcazar. 2007. "Disability, race/ethnicity and gender: themes of cultural oppression, acts of individual resistance." American Journal of Community Psychology 39(1-2):145-161.

Milligan, Maureen S. and Alfred H. Neufeldt. 2001. “The myth of asexuality: A survey of social and empirical evidence." Sexuality and Disability" 19(2):91-109.

Moin, Victor, Ilana Duvdevany, and Daniela Mazor. 2009. "Sexual Identity, Body Image and Life Satisfaction Among Women With and Without Physical Disability." Sexuality Disability 27:83-95.

Morris, Jenny. 1993. "Feminism and Disability." Feminist Review 1(43):57-70.

Moser, Ingunn. 2006. "Sociotechnical practices and difference: On the interferences between disability, gender, and class." Science, Technology and Human Values 31(5):537-564.

Nosek, Margaret A. 1996. “Wellness among women with physical disabilities." Pp. 17-33 in Women with physical disabilities: Achieving and maintaining health and well-being, edited by D. M. Krotoski, M. A. Nosek, and M. A. Turk. Baltimore: Brookes.

Nosek, Margaret A. and Rosemary B. Hughes. 2003. "Psychosocial Issues of Women with Physical Disabilities: The Continuing Gender Debate." Rehabilitation Counseling Bulletin 4(46):224-233.

Nosek, Margaret A. et al. 2003. "Self-esteem and women with disabilities." Social Science and Medicine 56:1737-1747.

Oyserman, Dafna. 2004. "Self-concept and identity." Pp. 5-24 in Self and Social Identity, edited by M. B. Brewer and M. Hewstone: Hoboken: Blackwell Publishing.

Piątek, Katarzyna. 2009. “Kilka uwag o trudnościach badawczych problemu niepełnosprawności - na przykładzie kobiet z niepełnosprawnością fizyczną." Pp. 217-224 in Metody, techniki i praktyka badań społecznych, edited by A. Bąk and Ł. Kubisz-Muła. Bielsko-Biała: Wydawnictwo Akademii Techniczno-Humanistycznej.

Riemann, Gerhard and Fritz Schütze. 1992. "'Trajektoria' jako podstawowa koncepcja teoretyczna w analizach cierpienia i bezładnych procesów." Kultura i Społeczeństwo 2(36):89-108.

Simon, Bernd. 2004. Identity in modern society: A social psychological perspective. Hoboken: Blackwell Publishing.

Stojkow, Maria and Dorota Żuchowska-Skiba. 2018. "Hybrid identities? Trajectories of the fate of old Muslim women in Poland." Revista Prisma Social 21:177-193.

Strauss, Anselm L. 1959. Mirrors and masks. The search for identity. Chicago: University of Chicago Press.

Strauss, Anselm L. 1995. “Identity, Biography, History, and Symbolic Representations." Social Psychology Quarterly 1(58):4-12.

Strauss, Anselm L. 2013. Zwierciadła i maski. W poszukiwaniu tożsamości. Kraków: Nomos.

Szczęsna, Ewa. 2004. “Tożsamość hybrydyczna." ER(R)GO 2(9):9-18.

Taleporos, George and Mariat McCabe. 2002. "The impact of sexual esteem, body esteem, and sexual satisfaction on psychological well-being in people with physical disability." Sexuality and Disability 20(3):177-183.

Thomas, Carol. 1997. "The Baby and the Bath Water: Disabled Women and Motherhood in Social Context." Sociology of Health and Illness 5(19):622-643.

Thomas, Carol. 1999. Female Forms: Experiencing and Understanding Disability. Buckingham: Open University Press.

Tøssebro, Jan. 2004. “Understanding disability: introduction to the special issues of SJDR." Scandinavian Journal of Disability Research 6(1):3-7.

Walsh, Anthony and Patricia Ann Walsh. 1989. "Love, self-esteem, and multiple sclerosis." Social Science and Medicine 7(29):793-798.

Wendelborg, Christian and Jan Tøssebro. 2010. "Marginalisation processes in inclusive education in Norway: a longitudinal study of classroom participation." Disability $\mathcal{E}$ Society 6(25):701-714.

Wołowicz-Ruszkowska, Agnieszka. 2013. Zanikanie? Trajektorie tożsamości kobiet z niepetnosprawnościa. Warsaw: Wydawnictwo APS. 


\title{
Citation
}

Żuchowska-Skiba, Dorota. 2020. "Hybrid identities? Trajectories of the Lives of Women with Acquired Disabilities." Przegląd Socjologii Jakościowej 16(3):70-82. Retrieved Month, Year (www.przegladsocjologiijakosciowej.org). DOI: http://dx.doi. org/10.18778/1733-8069.16.3.05

\section{Hybrydowe tożsamości? Trajektorie życia kobiet z niepełnosprawnościami nabytymi}

\begin{abstract}
Abstrakt: W badaniu nad niepełnosprawnością niezwykle istotną rolę odgrywają kwestie związane z przemianami tożsamości dokonującymi się pod wpływem doświadczeń, które zmieniają dotychczasowy bieg życia i wymuszają przyjęcie nowych ról i adaptację dotychczas wypełnianych. Taki charakter ma niepełnosprawność nabyta w dorosłym życiu. Stanowi ona punkt zwrotny powodujący transformację tożsamości kobiet, które muszą na nowo zdefiniować siebie i swoje miejsce w nowej dla nich rzeczywistości. Zasadniczym celem artykułu będzie ukazanie przemian, jakim podlegają tożsamości kobiet, które w wyniku wypadku nabyły niepełnosprawność w wieku dorosłym. Badania oparto o autobiograficzne wywiady narracyjne. Metoda ta pozwoliła na odtworzenie trajektorii życia respondentek, ukazując procesualny charakter kształtowanych przez nie tożsamości, które ulegały zmianom pod wpływem konieczności dopasowania się do warunków wynikających z nabytej niepełnosprawności. Badaniu poddano 6 kobiet zróżnicowanych pod kątem wieku, wykształcenia, pozycji zawodowej oraz sytuacji rodzinnej, które wpływały na realizowane przez nie role i zajmowane pozycje społeczne.
\end{abstract}

Słowa kluczowe: tożsamość, kobiety z niepełnosprawnością, niepełnosprawność nabyta, niepełnosprawność ruchu, punkt zwrotny 